\title{
ASSESSING THE IMPACTS OF CLIMATIC FACTORS ON COTTON YIELD AND ITS ECONOMIC INDICATORS
}

\author{
Assem A. A. MOHAMED ${ }^{1, *}$, Mona MAZE ${ }^{2}$, \\ Mohamed M. M. ABDELAZIZ ${ }^{1}$, Alaa A. KHALIL ${ }^{1}$ \\ *E-mail: assem20000@yahoo.com
}

Received: June 17, 2021. Revised: July 21, 2021. Accepted: Aug. 07, 2021. Published online: Aug. 11, 2021

\begin{abstract}
Cotton is one of the strategic crops in Egypt. This article investigates the impacts of climatic factors and their variations on the cotton yield and its economic benefits during the period from 1998 to 2019. We chose the Kafr El-Sheikh Governorate, where cotton is one of the major planted crops, was chosen for the analysis. The climatic factors utilized were the maximum, minimum and average temperatures; relative humidity; solar radiation and wind speed. Precipitation was excluded, as Egypt depends mainly on irrigation. The climatic factors utilized influenced yield during different growth stages: wind speed showed an influence only on the germination stage, whereas temperature had a major impact before and at the maturity stages. The latter correlation was positive in July and negative in August and September. Relative humidity and solar radiation impacted on yield at different growth stages, with an almost positive correlation with solar radiation and both a positive and a negative correlation with relative
\end{abstract}

humidity. For the study of the economic indicators of cotton, cotton data were taken for the whole Egyptian Governorate during the period 2005-2019. The study showed a decrease in the net return during the period from 2005 to 2015 that reached a loss (minus value) of 195 Egyptian pounds (LE) in 2015, followed by an increase during the period from 2016 to 2019 due to the increase in farm gate prices.

Keywords: cotton crops, weather parameters, vegetative stages, economic indicators, Egypt.

\section{INTRODUCTION}

Global warming is a major
environmental phenomenon that
impacts humans, animals and plants.
The global average land surface
temperature has increased by $0.78^{\circ} \mathrm{C}$
in the period $2003-2012$ compared
with $1850-1900$ and is expected to
increase by $4.8^{\circ} \mathrm{C}$ by 2100 , according

\footnotetext{
${ }^{1}$ Central Laboratory for Agricultural Climate (CLAC), Agricultural Research Center, Egypt

${ }^{2}$ Climate Change Information Centre and Renewable Energy (CCICRE), Agricultural Research Center, Egypt
} 
to the fifth assessment report of the United Nations Intergovernmental Panel on Climate Change (IPCC) (IPCC, 2013). Climate change is projected to have a significant impact on crop production across broad regions of the world in the $21^{\text {st }}$ century (Wang et al., 2017), where it is expected to increase the vulnerability of agricultural systems (Rosenzweig et al., 2014) by increasing temperature, causing changes in rainfall patterns and increasing the frequency of extreme weather events in most parts of the world (IPCC, 2014). Climate change and climate variability influences the total economy of a country as well as its individual households via different mechanisms. In addition to the agricultural intensification and increased crop productivity from various farming systems is accelerating the pressure on agricultural resources (Kong et al., 2015). Rising temperatures and changes in rainfall patterns also affect the agricultural yields of both rainfed and irrigated crops, and therefore impacts global and local food markets (Nelson et al., 2009, 2010).

Climate change has different impacts on both thermophilic and cryophilic crops. Rising air temperatures, including the daily maximum and minimum temperatures, cause changes in crop phenology. However, the daily minimum temperatures have a higher impact than the maximum temperatures, where the minimum temperatures have risen faster than daily maximum temperatures during recent decades (Menzel et al. 2001). The impacts of climate warming on plant phonologies are considered to be of major importance in the northern hemisphere, where the length of the growing season closely depends on temperature (Zhang et al. 2004; Chen et al. 2005; Linderholm 2006).

Cotton (Gossypium hirsutum L.) plays an important role in social and economic development (Amouzou etal., 2018), where it the most widely grown fiber crop globally. Over the last several decades, scientists have begun to consider the impacts of climate change on cotton production ( $\mathrm{Li}$ et al., 2019). The different climatic variables such as solar radiation, temperature, light, wind, rainfall, and dew, in addition to the length of the growing season, variety, availability of nutrients and soil moisture, pests and cultural practices affect cotton growth (El-Zik, 1980). The balance between vegetative and reproductive development can be influenced by soil fertility, soil moisture, cloudy weather, spacing and perhaps other factors such as temperature and humidity (Guinn, 1982). Temperature is a key factor for the whole growth period of cotton because it needs temperatures of 25$35^{\circ} \mathrm{C}$ and covers over 150 days (Boulakia et al., 2020) or at last 1,450 days (Lagandre 2005). Decreasing every $1^{\circ} \mathrm{C}$ in mean temperature will greatly delay maturity during the whole growth season (Roussopoulos et al., 1998), and higher temperatures will destroy cotton plant growth (David, 1971) and inhibit seed germination (Arndt, 1945). These will affect the phenologies and seed cotton yields. 
Cotton is one of the most important cash crops in Egypt, providing feed, fibre and oil. In Egypt, cotton seed yield was estimated to increase by $17 \%$ if the temperature increased by $2^{\circ} \mathrm{C}$ and by $31 \%$ with a $4^{\circ} \mathrm{C}$ increase (Eid et al., 1997). Cotton is also one of the best-known crops planted in the studied governorate (Kafr El-Sheikh). In this study, the linear tendency rate and correlation coefficient methods were used to analyse the impact of the different climatic variables (maximum, minimum and mean air temperature; relative humidity; solar radiation and wind speed), and their relationship to the cotton seed yield from 1998 to 2019 in Kafr El-Shiekh governorate. Moreover, the economic benefits of the cotton yield in Egypt during the period from 2005 to 2019 were considered.

\section{MATERIALS AND METHODS}

\section{Study site}

Kafr El-Sheikh is one of Nile Delta Region's governorates $\left(30^{\circ} 56^{\prime} \mathrm{E}, 31^{\circ} 06^{\prime} \mathrm{N}\right.$ and $17 \mathrm{~m}$ above sea level), which located in the north of Egypt, with a total area nearly $3466.69 \mathrm{~km}^{2}$ and is divided into 10 markazs, 11 cities and 69 rural local units. According to 2018 estimates, the governorate's population reached 3.414 million people. Kafr El Sheikh is an agricultural governorate, with total cultivated area of 550 thousand acres and is famous for producing rice, sugar beets, wheat and cotton. Most of the cultivated area $(98 \%)$ is old land (clay soil). All agricultural activity under this environment relies on irrigation (The Egyptian Cabinet Information and Decision Support System (IDSC, 2017).

\section{Weather and crop data}

Weather parameters, including daily relative humidity (\%), maximum and minimum temperatures $\left({ }^{\circ} \mathrm{C}\right)$, solar radiation $(\mathrm{MJ} / \mathrm{d})$ and wind speed $\left(\mathrm{m}^{2}\right)$, were recorded from 1998 to 2020 (Fig. 1). Weather data from March to September, which represent the planting and growth period of cotton, were used. The growth period of cotton is normally from midMarch to 10 August, but the harvest date could be prolonged to September in case of a late plating date (mid-April, at the latest). Therefore, the weather parameters were considered up to September. Weather data were collected from the Agriculture Research Centre (ARC) and The Central Laboratory for Agricultural Climate (CLAC) database. The total yield (tonnes/acre) of cotton in the Kafr ElSheikh governorate was collected from 1998 to 2019 (Fig. 2) from the Ministry of Agriculture and Land Reclamation (MALR) from 1998 to 2019. Genotype was not taken into consideration.

The reference crop evapotranspiration $\left(\mathrm{ET}_{0}\right)(\mathrm{mm} /$ day $)$ was calculated using the methodologies of Penman-Monteith (Allen et al., 1998), Valiantzas 1 and 2 (Valiantzas, 2013), using daily weather data for Kafr El-Sheikh from 1998 to 2019 in the months from March to September, with the following equations: 


$$
\begin{array}{lc}
E T_{0}=\frac{0.408 \Delta\left(R_{n}-G\right)+\gamma\left(\frac{C_{n}}{T_{\text {mean }}+273} u_{2}\right)\left(e_{s}-e_{a}\right)}{\Delta+\gamma\left(1+C_{d} u_{2}\right)} & \text { (Penman-Monteith) } \\
E T_{0}=0.00668 R_{a}\left(\left(T_{\text {mean }}+9.5\right)\left(T_{\text {max }}-T_{\text {min }}\right)^{0.5}-0.0696\left(T_{\text {max }}-T_{\text {min }}\right)-\right. \\
0.024\left(T_{\text {mean }}+20\right)\left(\frac{1-R H}{100}\right)-0.0045 R_{a}\left(T_{\text {max }}-T_{\text {dew }}\right)^{0.5}+0.0984\left(T_{\text {mean }}+\right. \\
17)\left(1.03+0.00055\left(T_{\text {max }}-T_{\text {min }}\right)^{2}-\frac{R H}{100}\right) & \text { (Valiantzas 1) } \\
E T_{0}=0.0051(1-\alpha) R_{s}\left(\left(T_{\text {mean }}+5\right)^{0.5}-2.4\left(\frac{R_{s}}{R_{a}}\right)^{2}+\right. & \\
0.048\left(T_{\text {mean }}+20\right)\left(1-\frac{R H}{100}\right)\left(0.5+0.536 u_{2}\right)+0.00012 z & \text { (Valiantzas 2) }
\end{array}
$$

where $(\Delta)$ is the slope of the saturation vapor pressure vs. air temperature curve $\left(\mathrm{kPa} \mathrm{C} \mathrm{C}^{-1}\right),\left(R_{n}\right)$ is the net radiation at the crop surface $\left(\mathrm{MJ} \mathrm{m}^{-2} \mathrm{~d}^{-1}\right),(G)$ is the soil heat flux density at the soil surface (MJ $\left.\mathrm{m}^{-2} \mathrm{~d}^{-1}\right),\left(T_{\max }, T_{\min }\right.$ and $\left.T_{\text {mean }}\right)$ are the max, min and mean daily air temperature at a height to $1.5-2.5 \mathrm{~m}\left({ }^{\circ} \mathrm{C}\right),\left(T_{\text {dew }}\right)$ is the dew temperature, $\left(u_{2}\right)$ is the mean daily wind

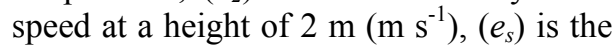
the saturation vapor pressure $(\mathrm{kPa}),\left(e_{a}\right)$ is the actual vapor pressure $(\mathrm{kPa}),\left(e_{s}-e_{a}\right)$ is the saturation vapor pressure deficit $(\mathrm{kPa})$, $(\gamma)$ is the psychrometric constant $\left(\mathrm{kPa}^{\circ} \mathrm{C}-\right.$ 1), $C_{n}=900^{\circ} \mathrm{C} \mathrm{mm} \mathrm{s}^{3} \mathrm{Mg}^{-1} \mathrm{~d}^{-1}$ for grassreference surface, $C_{d}=0.34 \mathrm{~s} \mathrm{~m}^{-1}$ and $\alpha=$ 0.25 . The crop evapotranspiration under standard conditions $\left(E T_{c}\right)$ was estimated using the procedures outlined by (Allen et al., 1998):

$$
E T_{c}=E T_{0} \times K_{c}
$$

where $\left(K_{c}\right)$ is the single crop coefficient, which incorporates crop characteristics and the averaged effects of evaporation from the soil, also differentiating between crop types and growth stages. $\left(K_{c}\right)$ is aggregated from the standard values of cotton from the FAO (Allen et al., 1998).

\section{Statistical analysis}

1. The Pearson (product-moment) correlation coefficient (r) was used to measure the linear relationship between the cotton seed yield (x) and the other variables (y) separately. The correlation coefficient was tested at a significance level of $p<0.05$. The Pearson's $\mathbf{r}$ is expressed mathematically by the following equation:

$$
r=\sum_{i}\left\{\left[x_{i}-\text { mean }(x)\right]\left[y_{i}-\text { mean }(y)\right]\right\}\left\{\sqrt{\sum_{i}}\left[x_{i}-\text { mean }(x)\right]^{2} \sqrt{\sum_{i}}\left[y_{i}-\text { mean }(y)\right]^{2}\right\}^{-1}
$$

\section{Ordinary least squares (OLS)} regression is a statistical method of analysis that estimates the relationship between one or more independent variables (climate variables) and a dependent variable (cotton seed yield); the method estimates the relationship by minimizing the sum of the squares in the difference between the observed and predicted values of the dependent variable configured as a straight line. The OLS helps by selecting the independent variables most correlated to the dependent one with $\mathrm{p}<0.05$.

\section{Economic impacts}

The economic impacts on seed cotton yield were evaluated during the period 2005-2019 for Egypt by using the simple regression method. The utilized input data as shown in Table 1 is the total Egyptian cultivated area (acre), seed 
cotton yield (tonnes/acre), production (thousands of tons), farm gate price (LE), cost of production (LE), total revenue (LE) and net return (LE). The data were collected from MALR (2005-2019).

\section{RESULTS}

\section{Impact of climate factors on seed} cotton yield in Kafr El-Sheikh

The seed cotton yield varied during the period from 1998 to 2018 (Fig. 2), starting slightly above 0.7 tonnes/acre in 1998 and increasing over the years to a maximum of 1.26 tonnes/acre in 2004 (monthly weather data are shown in Table 2). There was a subsequent decrease in yield to a minimum value of slightly less than 0.7 tonnes/acre in 2015 an another increase in 2016 to 1.0 ton/acre.

Following a slight increase to 1.12 tonnes/acre in 2018, there was another decrease in 2019 the level of 2017 with a value of 1.03 tonnes/acre. In general, the total cotton yield was slightly negatively correlated throughout the period from 1998 to 2019 , with a correlation coefficient (r) of -0.18 .

Table 1: Cultivated area, yield, total production, farm gate price, cost of production, total revenue and net return of cotton in Egypt during the period 2005-2019

\begin{tabular}{cccccccc}
\hline Years & $\begin{array}{c}\text { Cultivated } \\
\text { area } \\
\text { (Thousand } \\
\text { acre) }\end{array}$ & $\begin{array}{c}\text { Yield } \\
\text { (ton/acre) }\end{array}$ & $\begin{array}{c}\text { Total } \\
\text { production } \\
\text { (Thousand } \\
\text { ton) }\end{array}$ & $\begin{array}{c}\text { Farm } \\
\text { gate } \\
\text { price } \\
\text { (LE) }\end{array}$ & $\begin{array}{c}\text { Cost of } \\
\text { produc- } \\
\text { tion } \\
\text { (LE) }\end{array}$ & $\begin{array}{c}\text { Total } \\
\text { revenue } \\
\text { (LE) }\end{array}$ & $\begin{array}{c}\text { Net } \\
\text { return } \\
\text { (LE) }\end{array}$ \\
\hline 2005 & 656.6 & 0.980 & 643.45 & 733.0 & 2617 & 4675.0 & 2058 \\
\hline 2006 & 536.4 & 1.118 & 599.69 & 780.0 & 2965 & 5654.0 & 2689 \\
\hline 2007 & 574.6 & 1.080 & 620.54 & 671.0 & 3437 & 4736.0 & 1299 \\
\hline 2008 & 312.7 & 1.018 & 318.30 & 806.0 & 4120 & 5347.0 & 1227 \\
\hline 2009 & 284.4 & 0.989 & 281.3 & 677.0 & 3998 & 4401.0 & 403 \\
\hline 2010 & 369.1 & 1.023 & 377.6 & 1340.0 & 4571 & 8852.0 & 4281 \\
\hline 2011 & 520.1 & 1.220 & 634.5 & 1066.0 & 5193 & 8408.0 & 3215 \\
\hline 2012 & 333.4 & 0.881 & 293.7 & 1169.0 & 5490 & 6713.0 & 1223 \\
\hline 2013 & 286.7 & 0.881 & 252.6 & 1474.0 & 5626 & 8456.0 & 2830 \\
\hline 2014 & 369.2 & 0.834 & 307.9 & 1172.0 & 5916 & 6406.0 & 490 \\
\hline 2015 & 240.9 & 0.665 & 160.2 & 1245.0 & 5631 & 5436.0 & -195 \\
\hline 2016 & 131.8 & 1.090 & 144.61 & 2711.0 & 10736 & 19069.0 & 8333 \\
\hline 2017 & 217.0 & 1.190 & 258.23 & 2874.0 & 13491 & 21919.0 & 8428 \\
\hline 2018 & 336.0 & 1.270 & 426.7 & 3021.0 & 14953 & 24532.0 & 9579 \\
\hline 2019 & 239.4 & 1.174 & 281.14 & 3141.0 & 17010 & 23505.0 & 6495 \\
\hline Average & 440.8 & 1.04 & 465.5 & 1157.9 & $\mathbf{5 2 2 7 . 1}$ & 7936.2 & $\mathbf{2 7 0 9 . 1}$ \\
\hline & $\mathbf{4}$ & & &
\end{tabular}

Source: Compiled and calculated from: Economic Affairs Sector, MALR.

The reference crop evapotranspiration $\left(\mathrm{ET}_{\mathrm{o}}\right)$ depends mainly on the weather variables, where crop evapotranspiration under standard conditions $\left(\mathrm{ET}_{\mathrm{c}}\right)$ depends on both the weather variables and the crop type.
The lowest values of $\mathrm{ET}_{\mathrm{o}}$ and $\mathrm{ET}_{\mathrm{c}}$ (Fig. 3) were represented by the Penman-Monteith equation, with a range from 0.13 to 6.11 , which displayed an annual average of 3.2$3.8 \mathrm{~mm} /$ day, and a range from 0.06 to 
5.86, which displayed an annual average of 2.3-3 mm/day, for $\mathrm{ET}_{\mathrm{o}}$ and $\mathrm{ET}_{\mathrm{c}}$, respectively. Whilst Valiantzas equations 1 and 2 showed higher values that ranged between 1.79 and 0.74 , with an annual average of 5.7$6.6 \mathrm{~mm} /$ day, and between 0.57 and 9.78 , with an annual average of 4.8$5.6 \mathrm{~mm} /$ day, respectively for $\mathrm{ET}_{\mathrm{o}}$. For the $\mathrm{ET}_{\mathrm{c}}$ values, the Valiantzas 1 equation displayed a range from 0.82 to 9.87 , with an annual average of 4.2$5.0 \mathrm{~mm} /$ day and the Valiantzas 2 from 0.26 to 9.59 , with an annual average of 3.6-4.4 $\mathrm{mm} /$ day. According to the Penman-Monteith equation, the variation of the $\mathrm{ET}_{\mathrm{o}}$ and $\mathrm{ET}_{\mathrm{c}}$ through the studied years showed the highest values in the years 2000, 2001, 2008 and 2012 for, with an annual average of 3.6-3.9 mm/day for $\mathrm{ET}_{\mathrm{o}}$ and 2.7$3.0 \mathrm{~mm} /$ day for $\mathrm{ET}_{\mathrm{c}}$. The Valiantzas 1 equation gave annual averages of 6.3$6.6 \mathrm{~mm} /$ day for $\mathrm{ET}_{0}$ and $4.5-5.0 \mathrm{~mm} /$ day for $\mathrm{ET}_{\mathrm{c}}$, while the Valiantzas 2 equation showed the highest values of $\mathrm{ET}_{\mathrm{o}}$ and $\mathrm{ET}_{\mathrm{c}}$ in the years 2003, 2008 and 2016 with annual averages of 5.35.6 and 3.9-4.4 $\mathrm{mm} /$ day, respectively. However, the lowest values of $\mathrm{ET}_{0}$ and $\mathrm{ET}_{\mathrm{c}}$ were displayed in 2015 and 2020, with annual averages of 3.2-3.5 and 2.2-2.7 $\mathrm{mm} /$ day, respectively, according to the Penman-Monteith equation, 5.8-6.2 and 4.3-4.8 $\mathrm{mm} /$ day, respectively, according to Valiantzas 1 and 4.7-5.1 and 3.7-4.2 $\mathrm{mm} /$ day, respectively, according to Valiantzas 2.

The correlation coefficient $(r)$ between each weather parameter at each month of the cotton growing season and the cotton seed yield during the period 1998-2019 is represented in Fig. 4. The relative humidity showed a slight positive correlation with the seed cotton yield, with $r$ ranging from 0.1 to 0.3 , except for June, which showed no correlation between the relative humidity and seed cotton yield, and for July, which showed a relatively higher negative correlation between the relative humidity and seed cotton yield, with $\mathrm{r}$ equal to -0.4 . The maximum and minimum temperatures represented no correlation to a very slightly negative correlation with the seed cotton yield in the months from March to June. In July, there was a positive correlation between maximum and minimum temperatures and seed cotton yield, with $(r)$ values of 0.4 and 0.2 , respectively. The harvest months August and September showed a weak to strong negative correlation, with $(r)$ values of -0.7 and -0.2 for maximum temperature and -0.2 and -0.5 for minimum temperature, respectively. Solar radiation displayed only a positive correlation with the cotton seed yield, with a higher $(r)$ value in May of 0.4; the exception was April, which showed a slightly positive and negative correlations, with $(r)$ values that ranged between -0.2 to +0.2 , except for the planting month (March), when the wind speed was more negatively correlated with the seed cotton yield, with an $r$ value of -0.4 . 
Assem A. A. MOHAMED, Mona Maze, Mohamed M. M. ABDELAZIZ, Alaa A. KHALIL
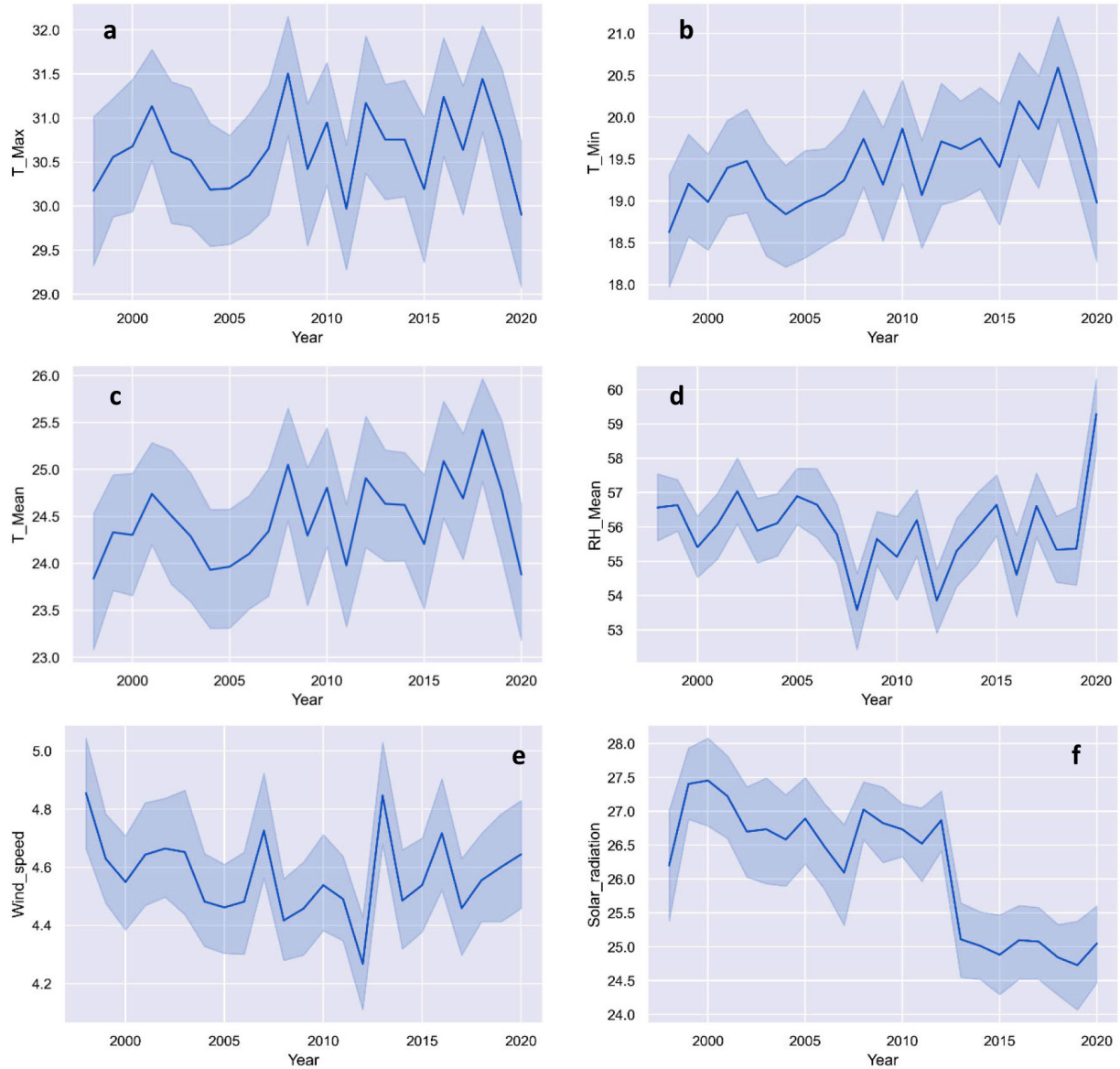

Figure 1. Climate variables during the study period at Kafr El-Sheikh: (a) Maximum temperature $\left({ }^{\circ} \mathrm{C}\right)$; (b) Minimum temperature $\left({ }^{\circ} \mathrm{C}\right)$; (c) Mean temperature $\left({ }^{\circ} \mathrm{C}\right)$; (d) Relative humidity (\%); (e) Wind speed $(\mathrm{m} / \mathrm{s})$ and $(\mathrm{f})$ Solar radiation $\left(\mathrm{MJ} / \mathrm{m}^{2}\right)$
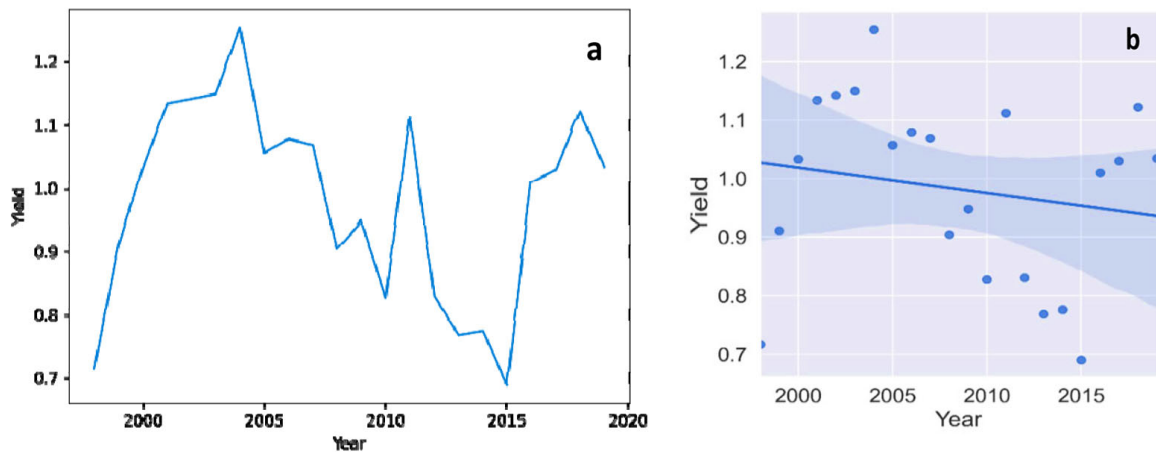

Figure 2. The seed cotton yield (tonnes/acre) a) value and b) its correlation during the period 1998-2019. 
Table 2: Average monthly weather data in the planting season of 2004, which shows the highest yield of 1.26 tonnes/acre.

\begin{tabular}{lcccccc}
\hline Month & $\mathbf{R H}(\%)$ & $\begin{array}{c}\text { Max } \\
\text { Temperature } \\
\left({ }^{\circ} \mathbf{C}\right)\end{array}$ & $\begin{array}{c}\text { Min } \\
\text { Temperature } \\
\left({ }^{\circ} \mathbf{C}\right)\end{array}$ & $\begin{array}{c}\text { Mean } \\
\text { Temperature } \\
\left({ }^{\circ} \mathbf{C}\right)\end{array}$ & $\begin{array}{c}\text { Wind } \\
\text { Speed } \\
(\mathbf{m} / \mathbf{s})\end{array}$ & $\begin{array}{c}\text { Solar } \\
\text { Radiation } \\
\left(\mathbf{M j} / \mathbf{m}^{2}\right)\end{array}$ \\
\hline March & 62.68 & 23.10 & 12.30 & 16.86 & 4.10 & 21.39 \\
\hline April & 55.43 & 25.65 & 14.32 & 19.45 & 4.72 & 24.47 \\
\hline May & 53.01 & 29.01 & 17.41 & 22.64 & 4.68 & 24.98 \\
\hline June & 55.78 & 32.06 & 20.07 & 25.64 & 4.50 & 29.73 \\
\hline July & 55.05 & 34.70 & 22.90 & 28.23 & 4.44 & 29.60 \\
\hline August & 57.43 & 33.55 & 23.20 & 27.71 & 4.30 & 27.19 \\
\hline
\end{tabular}
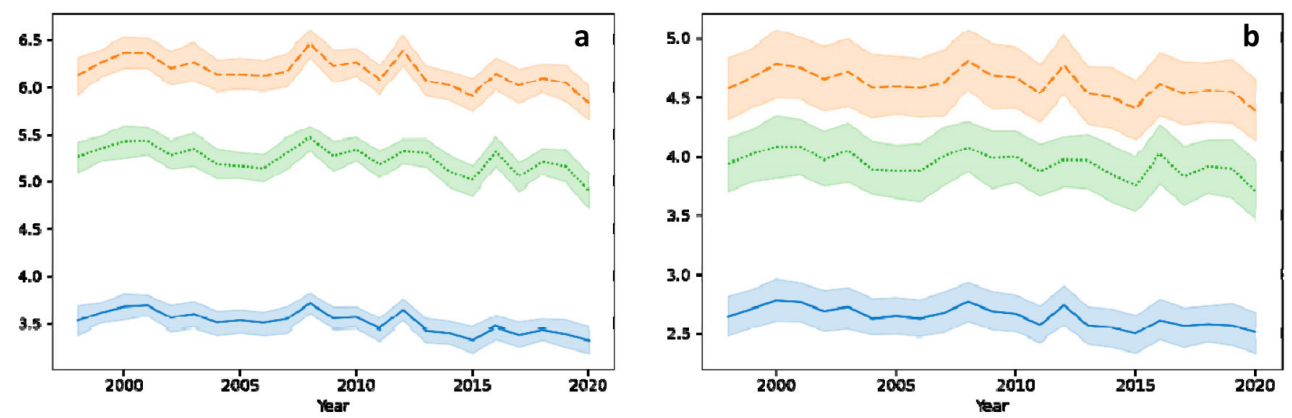

Figure 3. Calculation of the daily a) reference crop evapotranspiration $\left(E_{0}\right)$ and $\left.b\right)$ crop evapotranspiration under standard conditions $\left(\mathrm{Et}_{\mathrm{c}}\right)$ using the methodologies

Penman Monteith (Allen, et al., 1998), Valiantzas 1 and Valiantzas 2 (Valiantzas, 2013) for the period 1998-2020.

The ordinary least squares (OLS) regression model is represented in Table 3 with cotton seed yield as the dependent variable and the weather parameters for each month as the independent variables. The relative humidity showed a high correlation/ significant $p$-values $(p<0.05)$ according to the OLS regression model in the months of March, April, July and September, while the maximum temperature displayed significant p-values in April, July and August. The minimum temperature represented similar behaviour to the maximum temperature, where significant $p$ values were exhibited in May, July and
August. The wind speed variable showed significant $p$-values only at the beginning of March, whilst the solar radiation exhibited significant $\mathrm{p}$-values with cotton seed yield during most of the season in April, May, June, August and September. 
Assem A. A. MOHAMED, Mona Maze, Mohamed M. M. ABDELAZIZ, Alaa A. KHALIL

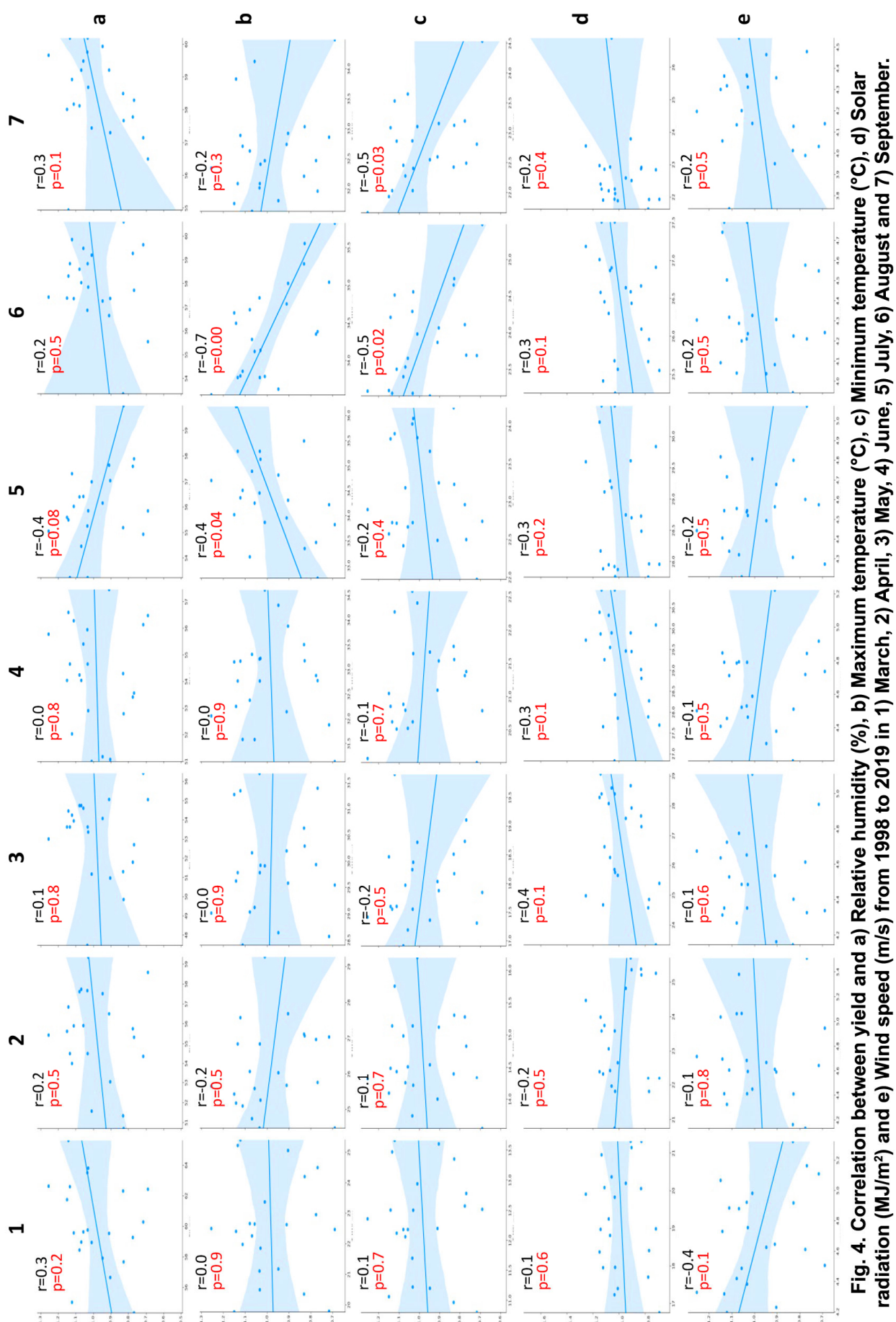


Table 3: OLS regression model results between cotton seed yield and the weather parameters for each month with $p<0.05$.

\begin{tabular}{|c|c|c|c|c|c|c|}
\hline \multicolumn{2}{|l|}{ Dep. Variable: } & Yield & \multicolumn{3}{|c|}{ R-squared: } & 0.990 \\
\hline \multicolumn{2}{|l|}{ Model: } & OLS & \multicolumn{3}{|c|}{ Adj. R-squared: } & 0.950 \\
\hline \multirow{2}{*}{\multicolumn{2}{|c|}{$\begin{array}{l}\text { Method: } \\
\text { No. Observations: }\end{array}$}} & & \multicolumn{3}{|c|}{ F-statistic: } & 24.40 \\
\hline & & 22 & \multicolumn{3}{|c|}{ Prob (F-statistic): } & 0.00351 \\
\hline \multicolumn{2}{|c|}{ Df Residuals: } & 4 & \multicolumn{3}{|c|}{ Loq-Likelihood: } & 61.110 \\
\hline \multirow{3}{*}{ Covariance Ty } & \multicolumn{2}{|r|}{17} & \multicolumn{3}{|c|}{ AIC: } & -86.22 \\
\hline & \multicolumn{2}{|c|}{ Non-robust } & \multicolumn{3}{|c|}{ BIC: } & -66.58 \\
\hline & Coefficient & std err & $\mathbf{t}$ & $P>|t|$ & {$[0.025$} & $0.975]$ \\
\hline Intercept & 42.8079 & 4.929 & 8.684 & 0.001 & 29.122 & 56.494 \\
\hline RH_mar & 0.0213 & 0.005 & 4.430 & 0.011 & 0.008 & 0.035 \\
\hline WS10M_mar & -0.2975 & 0.041 & -7.317 & 0.002 & -0.410 & -0.185 \\
\hline RH_apr & -0.0887 & 0.013 & -6.864 & 0.002 & -0.125 & -0.053 \\
\hline T_MAX_apr & -0.2592 & 0.026 & -9.877 & 0.001 & -0.332 & -0.186 \\
\hline SL̄R_apr & 0.1497 & 0.030 & 5.016 & 0.007 & 0.067 & 0.233 \\
\hline T_MIN_May & 0.1935 & 0.033 & 5.903 & 0.004 & 0.103 & 0.285 \\
\hline SLR May & 0.0467 & 0.014 & 3.378 & 0.028 & 0.008 & 0.085 \\
\hline SLR_jun & 0.0836 & 0.029 & 2.867 & 0.046 & 0.003 & 0.165 \\
\hline RH_jul & -0.2609 & 0.042 & -6.278 & 0.003 & -0.376 & -0.146 \\
\hline T_MAX_jul & -0.4126 & 0.080 & -5.161 & 0.007 & -0.635 & -0.191 \\
\hline T_MIN jul & 0.3443 & 0.054 & 6.369 & 0.003 & 0.194 & 0.494 \\
\hline RH_aug & 0.0704 & 0.014 & 4.947 & 0.008 & 0.031 & 0.110 \\
\hline T_MAX_aug & -0.1511 & 0.046 & -3.260 & 0.031 & -0.280 & -0.022 \\
\hline T_MIN_aug & -0.2256 & 0.062 & -3.624 & 0.022 & -0.398 & -0.053 \\
\hline SLER_aug & -0.4262 & 0.076 & -5.612 & 0.005 & -0.637 & -0.215 \\
\hline RH_sep & -0.0738 & 0.013 & -5.509 & 0.005 & -0.111 & -0.037 \\
\hline SLR_sep & 0.0987 & 0.016 & 6.218 & 0.003 & 0.055 & 0.143 \\
\hline
\end{tabular}

$\mathrm{R}^{2}$ : ratio of 'explained' variance to the 'total' variance of the dependent variable 'Yield'.

The coefficient of determination indicating goodness-of-fit of the regression.

Adjusted $\mathrm{R}^{2}$ : slightly modified version of $\mathrm{R}^{2}$, designed to penalize for the excess

number of regressors which do not add to the explanatory power of the regression.

Log-likelihood is calculated under the assumption that errors follow normal distribution.

Std err: standard errors of each coefficient estimate.

t: $t$-statistic for testing whether any of the coefficients might be equal to zero.

Large values indicate that the null hypothesis can be rejected and that

the corresponding coefficient is not zero.

P-value: expresses the results of the hypothesis test as a significance level.

P-values smaller than 0.05 are taken as evidence that the population coefficient is nonzero.

RH: Relative humidity (\%), T_MAX: Maximum temperature $\left({ }^{\circ} \mathrm{C}\right)$, T_MIN: Minimum temperature $\left({ }^{\circ} \mathrm{C}\right)$, SLR: Solar radiation $\left(\mathrm{MJ} / \mathrm{m}^{2}\right)$ and WS10M: Wind speed $(\mathrm{m} / \mathrm{s})$ for mar: March, apr: April, May: May, jun: June, jul: July, aug: August and sep: September.

Economic and production

\section{indicators of cotton in Egypt}

The Egyptian cultivated area of cotton during the period 2005-2019 decreased from a maximum 656.6 thousand acre in 2005 to the minimum 131.8 thousand acres in 2016 (Table 1), while it was increased 
again from 2017 to 2019 , with a total average of 440.8 thousand acres. The cultivated area of cotton had decreased at annual statistical significant rate of approximately (-) 500 acre during the study period with a coefficient of determination reached 0.69 (equation 1 in Table 4). However, the yield of cotton in Egypt was matched with the behaviour of seed cotton yield in Kafr El-Sheikh (Figure 2), where the highest values were represented in the years 2011 and 2018, with values 1.22 and 1.27 tonnes respectively, and the minimum value was 0.66 tonnes in
2015. The total production of cotton in Egypt showed a slightly different behaviour than the yield, where the highest values were represented in the years 2005, 2006, 2007 and 2011, with values of $643.4,599.7,620.5$ and 634.5 thousand, and the minimum value was 160.2 thousand tonnes in 2015. The total production of cotton had decreased at a statistically significant annual rate during the study period, with a coefficient of determination that reached 0.62 (equation 3 in Table 4).

Table 4: Linear trend equations for cotton cultivated area, yield, total production, farm gate price, cost of production, total revenue and net return in Egypt during the period 2005-2019

\begin{tabular}{|c|c|c|c|c|c|}
\hline Item & Equation & $\mathbf{R}^{2}$ & $\mathbf{F}$ & $\mathbf{T}$ & no \\
\hline Cultivated area & $\hat{Y} \mathrm{i}=711.10-499 \mathrm{X}_{1} \mathrm{i}$ & 0.69 & 37.08 & -6.09 & 1 \\
\hline Yield* $^{*}$ & $\hat{Y}_{i}=1.082-0.004 X_{2} i$ & 0.029 & 0.50 & -0.70 & 2 \\
\hline Total production & $\hat{Y}_{i}=771.29-30.58 X_{3} i$ & 0.624 & 28.18 & -5.31 & 3 \\
\hline Farm gate price & $\hat{Y}_{i}=-119.98+127.78 X_{4} i$ & 0.75 & 50.49 & 7.11 & 4 \\
\hline Cost of production & $\hat{Y}_{i}=-581.59+580.87 X_{5} i$ & 0.74 & 47.68 & 6.91 & 5 \\
\hline Total revenue & $\hat{Y} \mathrm{i}=-1104.49+904.07 \mathrm{X}_{6} \mathrm{i}$ & 0.61 & 26.49 & 5.15 & 6 \\
\hline Net return & $\hat{Y}_{i}=-522.9+323.2 X_{7 i}$ & 0.39 & 10.63 & 3.26 & 7 \\
\hline $\begin{array}{l}{ }^{*} \text { Nonsignificant } \\
\text { Where } \\
\hat{Y}_{i}=\text { the estimated va } \\
X_{i}=\text { the time variable } \\
i=1,2,3 \ldots . . .15 \\
R^{2}=\text { the determinatic } \\
F=\text { the F-statistic, th } \\
\text { the F-distribution unc } \\
T=\text { the t-statistic, res }\end{array}$ & $\begin{array}{l}\text { for the dependent variable in } \\
\text { he year i. } \\
\text { efficient. } \\
\text { sults of a statistical test in } \\
\text { he null hypothesis. } \\
\text { f a test on individual regres }\end{array}$ & year $i$. & statis & is $b$ & on \\
\hline
\end{tabular}

Table 1 illustrates that the evolution of farm gate prices during the study period reached a minimum of LE 671 in 2007, while the maximum was LE 3141 in 2019. Equation 4 in Table 4 shows that the farm gate prices of cotton had increased at a statistically significant annual rate during the period 2005-2019, and the coefficient of determination reached 0.75 . Therefore, the total cost of cotton production during the period 20052019 increased from a minimum of LE 2617 in 2005 to a maximum of LE 17010 in 2019, which represents a greater than 6-fold increase over the 
base year (Table 1). Equation 5 in Table 4 explains that the total cost of cotton production increased at a statistically significant annual rate, which reached LE 580.8 during the study period, and the coefficient of determination reached 0.74 . The total minimum revenue was LE 4401 in 2009, while the maximum showed a much higher value of LE 24532 in 2018. This explained the positive regression behaviour and regression coefficient of 0.61 in Equation 6 in Table 3. Finally, the net return on cotton fluctuated during the period 2005-2015, followed by an increase until 2019 due to increasing farm gate prices (Table 1). The net return showed a negative value of $195 \mathrm{LE}$ in 2015, and the maximum was LE 9579 in 2018. As shown in Equation 7 in Table 4, the net return of cotton had increased at a statistically significant annual rate of approximately LE 323 during the study period.

\section{DISCUSSION}

Rainfall was not considered here as one of the climatic factors that impacts the yield because of the precipitation scarcity in the region and the full dependence on irrigation. The reference crop evapotranspiration $\left(\mathrm{ET}_{\mathrm{o}}\right)$ and crop evapotranspiration under standard conditions $\left(\mathrm{ET}_{\mathrm{c}}\right)$ were calculated to show the variation in water requirements during the studied period to sustain the best yield, where the $\left(\mathrm{ET}_{\mathrm{o}}\right)$ value varied depending on the climatic factors. $\left(\mathrm{ET}_{\mathrm{o}}\right)$ and $\left(\mathrm{ET}_{\mathrm{c}}\right)$ displayed the same behaviour with all three algorithms used for calculation
(Fig. 3). Three $\left(\mathrm{ET}_{\mathrm{o}}\right)$ equations were utilized, Penman-Monteith, Valiantzas 1 and Valiantzas 2, which were classified by Djaman et al. (2015) as the best equations for calculating the $\left(\mathrm{ET}_{\mathrm{o}}\right)$. The Penman-Monteith equation gave the lowest $\left(\mathrm{ET}_{\mathrm{o}}\right)$ and $\left(\mathrm{ET}_{\mathrm{c}}\right)$ values, while Valiantzas 1 gave higher values, and Valiantzas 2 gave the highest values. The behaviour of $\left(\mathrm{ET}_{\mathrm{o}}\right)$ and $\left(\mathrm{ET}_{\mathrm{c}}\right)$ were highly positively correlated with the trends in maximum and minimum temperatures (Fig. 1), where the highest annual average $\left(\mathrm{ET}_{\mathrm{o}}\right)$ and $\left(\mathrm{ET}_{\mathrm{c}}\right)$ values in 2000,2001 , 2008 and 2012 coincided with the highest annual average maximum and mean temperatures, given that higher temperatures lead to faster water evaporation. As well, the lowest annual average $\left(\mathrm{ET}_{\mathrm{o}}\right)$ and $\left(\mathrm{ET}_{\mathrm{c}}\right)$ values in 2011, 2015 and 2020 were coincident with the lowest annual average maximum and mean temperatures. Nevertheless, the years 2017 and 2019 faced high maximum and minimum temperatures but not a very high $\left(\mathrm{ET}_{\mathrm{o}}\right)$ and $\left(\mathrm{ET}_{\mathrm{c}}\right)$ values as in 2008 and 2012 because of the low solar radiation values from 2014 to 2020.

Relative humidity showed a positive correlation (Fig. 4) with yield during the growth months starting from March to September, but in July, relative humidity was correlated negatively with yield. The correlation of relative humidity $(\mathrm{RH})$ with yield during the plant growth months explained that higher relative humidity has a greater effect on yield than lower humidity. This result agrees with Barbour \& Farquhar (2000), who 
reported that plants grown at lower $\mathrm{RH}$ had higher transpiration rates, lower leaf temperatures and lower stomatal conductance, and plant biomass was reduced at lower RH. Sawan (2018) confirmed the positive relationship between RH and yield, explaining that a modest decrease in humidity would cause a significant reduction in boll number. Sawan (2018) also noted that $\mathrm{RH}$ is one of the most effective and consistent climatic factors affecting boll production, which explains the significance of RH in the OLS regression model (Table 3) in the months of March, April, July and September $(\mathrm{p}<0.05)$.

The wind speed showed a high negative correlation with yield only in March (Fig. 4), which was also the only month that existed in the OLS regression model table (Table 3). March represented the emergence and the beginning of the first square phonological stages, where the plant at the beginning of its growth is vulnerable to high wind speed. Solar radiation showed a slight positive correlation with yield, except in April, which corresponded the first square growth stage, displaying a negative correlation with yield. In May, which corresponded the flowering growth stage, solar radiation exhibited a high correlation with yield.

Temperature is a major factor controlling rates of plant growth and yield. Burke et al. (1987) reported that the optimum temperature range for cotton growth is $23.5-32^{\circ} \mathrm{C}$, with an optimum temperature of $28^{\circ} \mathrm{C}$, while Schrader et al. (2004) stated that high temperatures had negative impacts on plants by inhibiting photosynthesis. The maximum and minimum temperatures represented no correlation to a very slight (positive and negative) correlation with yield from March to June (Fig. 4), where heat waves were rare and the maximum temperature did not declined to $12^{\circ} \mathrm{C}$. Studies have shown that a low temperature $\left(<12^{\circ} \mathrm{C}\right)$ in the early stage of cotton growth leads to delayed growth and development (Hodges et al., 1993; Pettigrew, 2008; Snider et al., 2010), whereas in the latter growth stages in August and September, the maximum and minimum temperatures displayed a high negative correlation with yield in agreement with Hodges et al. (1993), who found that cotton fruit retention decreased rapidly as the time of exposure to $40^{\circ} \mathrm{C}$ increased; Sawan (2018), who noted that the combination of high maximum temperatures (up to $44^{\circ} \mathrm{C}$ ) may have an adverse effect on flower and boll formation; and Snider et al. (2010), who stated that a high temperature $\left(>35^{\circ} \mathrm{C}\right)$ in the middle stage of growth can have a detrimental effect on the fertilization rate, cotton boll volume, and the quantity of cottonseed buds that fall off (Hodges et al., 1993; Pettigrew, 2008). Nevertheless, the maximum temperatures in July with a range of $30.1-42.9^{\circ} \mathrm{C}$, which included 5 days with $>40^{\circ} \mathrm{C}$ temperatures and minimum temperatures in the range of 20.4-26. $7^{\circ} \mathrm{C}$, showed a positive correlation with the yield. 
The rising global temperature, a result of climate change, could lead to shortening of the developmental stage of cotton and affect crop yields because shortening of the plant growing season leads to the absorption of less radiation and reduction of biomass and yield (Chmielewski et al. 2004). But Eid et al. (1997) stated that the cotton seed yield would increase by $17 \%$ if the temperature increased by $2^{\circ} \mathrm{C}$ and by $31 \%$ with a $4^{\circ} \mathrm{C}$ increase.

The net return value depends on the amount of the increase in total revenue compared to the increase in production cost. The net return behaviour was similar to the total seed cotton yield in Egypt (Table 1) and even to the seed cotton yield in the Kafr El-Sheikh governorate (Figure 2), with a high value in 2018 and low value (negative) in 2015. The significant increase in the values of farm gate price, cost of production, total revenue and net return starting from 2016 to 2019 compared with the preceding period, was due to the significant increase in the dollar value compared to the Egyptian pound. Despite of the increase of the dollar value compared to the Egyptian pound, the net return at the period from 20162019 also represented higher values due to its positive correlation with the yield and, therefore, with farm gate prices

\section{CONCLUSIONS}

Cotton seed yield has fluctuated between increasing and decreasing during the period 1998 - 2019 in Kafr El-Sheikh, with an overall slight decrease in the rate of -0.18 . The relationship between climatic variables and cotton yield indices was investigated in this study. Pearson's correlation was used to analyse the correlation between each climatic variable and the cotton seed yield. The correlations were positive or negative and were mostly insignificant during the different growth stages. The most significantly correlated climatic variables were the maximum and minimum temperatures, which were highly negatively correlated with the yield at the maturity stages in August and September, but positively in July. However, the maximum and minimum temperatures showed low to no correlation at the early growth stages, where the temperatures did not fall beyond the minimum required temperature for cotton growth. The relative humidity was also an important climatic variable that displayed a slight to moderate correlation with yield at almost all the growth stages, where higher relative humidity most affects growth. Wind speed is only impactful at the beginning of plant growth. The significant correlation between wind speed and yield was displayed negatively in March (emergence and the beginning of the first square). Finally, the correlation between solar radiation and cotton seed yield fluctuated between positive and negative, slightly to relatively strong correlated during the growth stages. The climatic variable precipitation was not taken into consideration, as cotton depends mainly on irrigation. However, the $\left(\mathrm{ET}_{\mathrm{o}}\right)$ and $\left(\mathrm{ET}_{\mathrm{c}}\right)$ 
calculated with the different utilized algorithms were highly correlated mainly with the maximum and mean temperatures. For the economic impacts on cotton yield in Egypt, the net return showed a decrease during the period 2005-2015, followed by an increase in the period 2016-2019 due to the increase in farm gate prices.

\section{REFERENCES}

Allen, R.G., Pereira, L.S., Raes, D., Smith, M., 1998. Crop evapotranspiration: guidelines for computing crop water requirements.FAO Irrigation and Drainage Paper No. 56. FAO, Rome.

Amouzou, K. A., Naab, J. B., Lamers, J. P. A., Borgemeister, C., Becker, M., \& Vlek, P. L. G. (2018). CROPGROCotton model for determining climate change impacts on yield, water- and $\mathrm{N}$ - use efficiencies of cotton in the Dry Savanna of West Africa. Agricultural Systems, 165, 85-96. DOI: 10.1016/j.agsy.2018.06.005

Bange, M., 2007. Effects of climate change on cotton growth and development. Australian Cottongrower, 28 (2007), pp. 41-45

Barbour, M. M., \& Farquhar, G. D. (2000). Relative humidity- and ABA-induced variation in carbon and oxygen isotope ratios of cotton leaves. Plant, Cell \& Environment, 23(5), 473-485. DOI: $\quad 10.1046 /$ j.1365-3040.2000.005 75.x

Burke, J. J., Mahan, J. R., \& Hatfield, J. L. (1988). Crop-Specific Thermal Kinetic Windows in Relation to Wheat and Cotton Biomass Production. Agronomy Journal, 80(4), 553-556. DOI: 10.2134/agronj1988.000219620 $08000040001 \mathrm{x}$

Chen, X., Hu, B., \& Yu, R. (2005). Spatial and temporal variation of phenological growing season and climate change impacts in temperate eastern China. Global Change Biology, 11(7), 1118-1130. DOI: 10.1111/j.1365-2486.2005.00974.x

Chmielewski, F.-M., Müller, A., \& Bruns, E. (2004). Climate changes and trends in phenology of fruit trees and field crops in Germany, 1961-2000. Agricultural and Forest Meteorology, 121(1-2), 69-78. DOI: 10.1016/s0168 $-1923(03) 00161-8$

Boulakia, S., Tivet, F., Husson, O., ... Séguy, L. (2020). Nutrient management practices and benefits in Conservation Agriculture systems. Burleigh Dodds Series in Agricultural Science, 169-198. DOI: 10.19103/as. 2019.0049 .06

Eid HM, EI-Marsafawy SM, Salib AY \& Ali MA, 1997. Vulnerability of Egyptian cotton productivity to climate change. Meteorology \& Environmental Cases Conference, Cairo, Egypt, 2-6 March.

El-Zik, K.M. (1980). The cotton plantFits growth and development. Western Cotton Production Conference Summary Proceedings, pp. 18-21, Fresno, CA.

Guinn, G. (1982). Causes of square and boll shedding in cotton. USDA Technical Bulletin 1672.

Hodges, H.F., Reddy, K.R., McKinion, J.M. \& Reddy, V.R. (1993). Temperature effects on cotton. Bulletin of Mississippi Agricultural Forestry Experimental Station, 990: 15.

IPPC (Intergovernmental Panel on Climate Change) (Ed.). (n.d.). Summary for Policymakers. Climate Change 2013 - The Physical Science Basis, 1-30. DOI: 10.1017/ cbo9781107415324.004

IPCC (Intergovernmental Panel on Climate Change) (Ed.), 2014. Climate Change 2014 Synthesis Report Summary Chapter for Policymakers 31 IPCC. DOI: 10.1017 /CBO9781107415324.

Kong, X., Zhang, X., Lal, R., Zhang, F., Chen, X., Niu, Z., ... Song, W. (2016). Groundwater Depletion by 


\section{ASSESSING THE IMPACTS OF CLIMATIC FACTORS ON COTTON YIELD}

Agricultural Intensification in China's $\mathrm{HHH}$ Plains, Since 1980s. Advances in Agronomy, 59-106. DOI: 10.1016/bs.agron.2015.09.003

Lagandre D (2005). Le secteur cotonnier en zone franc, entresuccès et dépendance. Rapport thématique JUMBO 7. Agence Française de Développement.

Li, N., Lin, H., Wang, T., Li, Y., Liu, Y., Chen, X., \& Hu, X. (2020). Impact of climate change on cotton growth and yields in Xinjiang, China. Field Crops Research, 247, 107590. DOI: 10.101 6/j.fcr.2019.107590

Linderholm HW (2006). Growing season changes in the last century. Agr Forest Meteorol 137:1-14.

Ministry of Agriculture and Land Reclamation (MALR), Economic Affairs Sector, Study of Important Indicators of the Agricultural Statistics (Summer \& Nili Crops), 1998- 2019.

Ministry of Agriculture and Land Reclamation (MALR), Economic Affairs Sector, Bulletin of Agricultural Price Statistics, 2005- 2019.

Menzel, A., Estrella, N., \& Fabian, P. (2001). Spatial and temporal variability of the phenological seasons in Germany from 1951 to 1996. Global Change Biology, 7(6), 657-666. DOI: /10.1111/j.1365-2486. 2001.00430.x

Nelson, G.C., Rosegrant, M., Palazzo, A., Gray, I., Ingersoll, C., Robertson, R., Tokgoz, S., Zhu, T., Sulser, T.B., Ringler, C., Msangi, S., You, L., 2010. Food security, farming, and climate change to 2050: Scenarios, Results, Policy Options. (2010). DOI: 10.2499/9780896291867

Nelson, G.C., Rosegrant, M.W., Koo, J., Robertson, R., Sulser, T., Zhu, T., Ringler, C., Msangi, S., Palazzo, A., Batka, M., Magalhaes, M., Valmonte-Santos, R., Ewing, M., Lee, D., 2009. Climate change: impact on agriculture and costs of adaptation

Gerlad C. Nelson, Mark W. Rosegrant, Jawoo Koo, Richard Robertson, Timothy Sulser, Tingju Zhu,
Claudia Ringler, Siwa Msangi, Amanda Palazoo, MIroslav Batka, Marilia Magalhaes, Rowena Valmonte-Santos, Mandy Ewing, and David Lee. (2009). DOI: 10.29171/azu_acku_pamphlet_ge14 9_n457_2009

Pettigrew, $\overline{\mathbf{W}}$. T. (2008). The Effect of Higher Temperatures on Cotton Lint Yield Production and Fiber Quality. Crop Science, 48(1), 278-285. DOI: 10.2135/cropsci2007.05.0261

Rosenzweig, C., Jones, J. W., Hatfield, J. L., Ruane, A. C., Boote, K. J., Thorburn, P., ... Winter, J. M. (2013). The Agricultural Model Intercomparison and Improvement Project (AgMIP): Protocols and pilot studies. Agricultural and Forest Meteorology, 170, 166-182. DOI: 10.1016/j.agrformet.2012.09.011

Roussopoulos, D., Liakatas, A., \& Whittington, W. J. (1998). Controlled-temperature effects on cotton growth and development. The Journal of Agricultural Science, 130(4), 451-462. DOI: 10.1017/s0021 859698005401

Sawan, Z. M. (2018). Information about the Effect of Climatic Factors and Soil Moisture Status on Cotton Production using Different Statistical Relations. Significances of Bioengineering \& Biosciences, 2(1). DOI: 10.31031/ sbb.2018.02.000529

Schrader, S. M., Wise, R. R., Wacholtz, W. F., Ort, D. R., \& Sharkey, T. D. (2004). Thylakoid membrane responses to moderately high leaf temperature in Pima cotton. Plant, Cell and Environment, 27(6), 725735. DOI: 10.1111/j.1365-3040.2004. 01172.x

Snider, J. L., Oosterhuis, D. M., Skulman, B. W., Kawakami, E. M., 2010. Heat stress-induced limitations to reproductive success in Gossypium hirsutum. Physiol. Plant. 137 (2), 125-138.

Snider, J. L., Oosterhuis, D. M., Skulman, B. W., \& Kawakami, E. M. (2009). Heat stress-induced limitations to reproductive success 
Assem A. A. MOHAMED, Mona Maze, Mohamed M. M. ABDELAZIZ, Alaa A. KHALIL

inGossypium hirsutum. Physiologia Plantarum, 137(2), 125-138. DOI: 10.1111/j.1399-3054.2009.01266.x

Valiantzas, J. D. (2013). Simplified forms for the standardized FAO-56 Penman-Monteith reference evapotranspiration using limited weather data. Journal of Hydrology, 505, 13-23. DOI: 10.1016/j.jhydrol. 2013.09.005

Wang, Z., Chen, J., Xing, F., Han, Y., Chen, F., Zhang, L., Li, C. (2017). Response of cotton phenology to climate change on the North China Plain from 1981 to 2012. Scientific Reports, 7(1). DOI: 10.1038/s41598017-07056-4

Zhang, L., Werf, W. V. D., Cao, W., Li, B., Pan, X., \& Spiertz, J. H. J. (2008). Development and validation of SUCROS-Cotton: a potential crop growth simulation model for cotton. NJAS. Wageningen Journal of Life Sciences, 56(1-2), 59-83. DOI: 10.10 16/s1573-5214(08)80017-6 